\title{
MILESTONES, DISCIPLINES AND THE FUTURE OF INITIATIVES OF READING AND WRITING IN HIGHER EDUCATION: AN ANALYSIS FROM KEY SCHOLARS IN THE FIELD IN LATIN AMERICA
}

\author{
Mónica Tapia-Ladino* \\ Universidad Católica de la Santísima Concepción \\ Concepción, CL \\ Natalia Ávila Reyes ${ }^{* *}$ \\ Pontificia Universidad Católica de Chile \\ Santiago, CL \\ Federico Navarro ${ }^{* * *}$ \\ Universidad de Buenos Aires \\ Buenos Aires, AR \\ Universidad de Chile \\ Santiago, CL \\ Charles Bazerman ${ }^{* * *}$ \\ University of California Santa Barbara \\ Santa Barbara, US
}

\begin{abstract}
This paper aims to understand the initial milestones, causes, academic activities, theoretical foundations and disciplines involved in the scholarly development of Higher Education reading and writing studies in Latin America. Eight academic leaders from Argentina, Chile, Colombia, and México were interviewed in order to learn their perspectives on this development. Findings reveal that the main founding milestones are conferences starting by the 2000's decade; the UNESCO Chair is the current main academic network that congregates scholars interested in this topic; the reasons for the field's emergence are related to the increasing growth in college enrolments. Overall, a growing interdisciplinary field can be observed, but its disciplinary identity is still diffuse, given the ongoing jurisdictional disputes.
\end{abstract}

Keywords: Academic Writing; Academic Disciplines; ILEES Group; Qualitative Analysis; Disciplinarity

\footnotetext{
${ }^{*}$ Ph.D in Linguistics and Assistant Professor at the Language Department at UCSC, she has participated in research projects about writing in higher education and in the Chilean school system. She has served as the director of the Applied Linguistics Master Program and is currently the Vice Chancellor of Academic Affairs at UCSC, Chile. Her email address is mtapia@ucsc.cl

${ }^{* *}$ A Chilean scholar, she is an Assistant Professor in Didactics at the Faculty of Education in Pontifica Universidad Católica de Chile. She is also a member of the international research network ILEES (www.ilees.org). Her interests are postsecondary writing and writing in disciplines, and her latest research project traces the emergence of this field in Latin America. Her email address is naavila@uc.cl

${ }^{* * *}$ An assistant professor and researcher at the University of Buenos Aires and CONICET (Argentina), he has served as a writing program administrator at school and university levels. He has published his research in Argentina, Brazil, Chile, Mexico, Spain, Portugal, Switzerland and the United States. His research includes academic writing teaching, discourse analysis, and disciplinary inquiry in writing studies and linguistics. His email address is fnavarro@conicet.gov.ar

${ }^{* * * *}$ Professor of Education at the University of California Santa Barbara, Steering Committee Chair of the International Society for the Advancement of Writing Research, and recent chair of the Conference on College Composition and Communication. His books include A Rhetoric of Literate Action, A Theory of Literate Action, The Languages of Edison's Light, Constructing Experience, Shaping Written Knowledge, The Informed Writer, and The Handbook of Research on Writing. Several volumes of his essays have been translated into Portuguese and Spanish, and he has worked with campuses throughout Latin America. His email address is bazerman@education.ucsb.edu
} 


\section{Introduction}

In Latin America, as in many parts of the world, the emergence of institutional and professionalized opportunities for teaching and supporting academic writing in Higher Education is relatively recent (Cadena \& Narváez-Cardona, 2008; Perales \& Escudero, 2010; Bazerman et al., 2009, 2012; Navarro, 2012; Thaiss, Bräuer, Carlino, Ganobcsik-Williams \& Sinha, 2012; Ávila Reyes, González \& Peñaloza, 2013), and has led to a period of unprecedented expansion and development (Bazerman et al., 2016). The reasons and the influences that promoted this expansion, along with the disciplines involved in its development, are varied and diverse and their history has been scarcely looked upon. This is why there seem to be contrasting views on its emergence; while some authors identify initiatives that date back to the end of the 1980s (Pereira, 2006), others think this became a research subject matter as recently as 2003 (Carlino, 2013) or link it to the establishment in 1994 of one of the major local networks that have gathered scholars in this field, the UNESCO Chair/Regional Network for the improvement of education quality and equity in Latin America (Reading and Writing) (Navarro et al., in press). Although these different dates can be found in literature, a broader and comprehensive narrative on this issue had not been offered yet.

While many recent projects attempt to summarize the progress, development and consolidation of writing studies in Higher Education, they generally approach the topic from the particular experiences of programs or research groups (Thaiss et al., 2012; Carlino, 2013). In contrast, this article seeks to describe the development and current state of reading and writing studies in Higher Education through the content analysis of interviews to scholars from Argentina, Chile, Colombia and Mexico identified by their peers as key figures. Drawing from a qualitative and interpretive perspective (Merriam, 2009; Patton, 2015), the objective of this study is to offer a comprehensive landscape of the field in the region by identifying elements that might be informative of its current development and its disciplinary status. Therefore, we aim to offer a representative, replicable, aggregable and data-driven scholarly investigation
(Haswell, 2005) on the disciplinary configuration of the field. To this end, the research questions were: (1) Which are the milestones, influences, interests and activities related to Higher Education reading and writing teaching and research in Latin America?, and (2) Is this an emerging disciplinary space with a recognizable identity or a juxtaposition of scholars from different traditions interested in a single topic?

This paper is part of a greater initiative called Initiatives of Reading and Writing in Higher Education in Latin America (www.ilees.org), made up of scholars from Argentina, Brazil, Chile, Colombia, Mexico and the United States. The objective of this project is to identify and make available research and teaching activities on reading and writing at a tertiary level. As a part of the data collection stage, a survey was given to academics associated with different types of initiatives on reading and writing in Higher Education from Argentina, Chile, Colombia and Mexico. As a result of this survey, eight key informants - two from each country - were identified, who in turn made up the sample of this study for in-depth interviews. The interviews aimed at identifying the initial milestones, causes, academic activities, theoretical foundations and disciplines involved in the scholarly development of the field in Latin America.

In what follows, firstly, we explore the theoretical framework that informs this paper; key concepts to understand better (inter)disciplinary dynamics and jurisdictional claims are provided; this framework also suggests the importance of boundary work in emerging disciplines to gain status within the academy. Secondly, we explain the methodology to select interviewees, choose interview questions and analyze data. Thirdly, we show and interpret the results of the analysis, organized as a sequence of topics. Finally, in the Discussion, we argue the main trends found and the status of the discipline.

\section{Reference framework}

In this paper we seek to describe the elements of an emerging discipline as it is represented in its main constitutive elements described by its participants, 
some of them, local pioneers. However, the mere fact of considering reading and writing studies as an "emerging discipline" can be contested. While some might regard it as an interdisciplinary emerging field that already has one or two decades of development, others might consider it as just a research topic, developed within the limits of other established disciplines, which gathers a heterogeneous group of scholars. Indeed, even from our insider's perspective, it is hard to define a single or main discipline of origin for writing studies; it well might be education, linguistics, psychology, or even student services units. Moreover, the disciplinary status of "language didactics", or an educational, first language "applied linguistics" is also diffuse. Furthermore, a specific name with which to refer to this thematic unit has yet to be clearly defined, oscillating from the more established "academic literacy" (Carlino, 2005; Parodi, 2010) to broader descriptions such as "writing studies in Higher Education", preferred by our team (Bazerman et al., 2016; Navarro et al., in press).

Becher (1989) claims that simply using a structural framework of reference, such as departmental distribution in the university system, is not enough for understanding an academic discipline, nor the place it occupies in the knowledge landscape. That was the case found when we first conducted the ILEES survey (Bazerman et al., 2016; Bork, Bazerman, Correa \& Cristovão, 2014); inquiring on departmental houses of respondents did not yield to clear results for that matter. Academic units were so many and so dispersed that we failed to identify an "academic home" (Poole, 2009) for the field.

This failure might be further explained by the structure and increasing diversity of Latin American university system. Firstly, Latin American university system follows a model of early specialization, starting with professional or academic undergraduate programs. Secondly, the diversity of these programs might be huge across local contexts. For example, an undergraduate program in education leads to a professional teaching credential in Chile, whereas in Argentina it leads to an academic degree focused on research and administration. Faculty and departmental names might have very different meanings. Additionally, there is an increasing institutional diversity in types of institutions, sources of funding (public, private and mixed) and the number of students each institution serves (Mollis, 2003). Lastly, there might also be a coexistence of multiple "parent disciplines" for a newly interdisciplinary, specialized field (Becher, 1989), with fuzzier disciplinary boundaries and cross-fertilizations (Klein, 1996, 2008).

These particularities of Latin American writing studies in Higher Education and the dynamic nature of disciplinary formations have called for a different approach for studying the emergence of the field. Interdisciplinary activities and emergent fields often engage in "boundary work", which consists on different forms of claiming legitimacy, mainly by researching the field's own production and history, such as the case of this project. The methods used for doing this are borrowed from knowledge studies literature and usually include, alongside disciplinary histories, "genealogy, ethnography, interviews and surveys, bibliometrics, discourse analysis, archival research, organizational analysis, social theory, and critique" (Klein, 2000, p. 7).

\subsection{Milestones, causes and future: unraveling a historical perspective}

Although this work does not attempt a comprehensive historical account of the field, tracing milestones, causal explanations and future perspectives serves the function of dating and historicizing the emergence of the field's activities. Moreover, by identifying the field's foundational events, people and forces, we can get valuable insights on its current formation (Goggin, 2000). As a matter of fact, in the different "causes" identified by scholars for the emergence of the topic, key information for understanding differential epistemologies or current disciplinary disputes might be found.

Milestones such as the founding of programs and networks are usually understood as tokens of disciplinarity. Toulmin (1972) mentions, among others, the establishment of professional associations and scientific journals, a topic also referred by Becher (1989) and Goggin (2000). In fact, there are some 
previous studies in Latin America that seek to link the emergence and current state of disciplinary fields with their discourses, scholarly journals and institutions (Vallejos Llobet, 2005 for Physics or Ciapuscio, 2007, for Linguistics, both in Argentina). Becher also mentions internationalization of the emergent topic of study as a factor to consider. The establishment of $\mathrm{PhD}$ programs can be added to these gauges of disciplinarity; doctors in a given discipline are responsible for mastery of a body of knowledge and for instructing the next generation of students in the field (Jacobs, 2013). In Latin America these might also include specialization and master's programs. The sum of these factors is of capital importance when inquiring about disciplinary status of writing studies in the region.

Overall, historical landmarks are important for disciplinary inquiry. As Goggin puts it, "disciplinary histories in particular serve a crucial function in legitimizing intellectual communities and in helping to secure them a place in academia" (2000, p. xiv).

\subsection{Activities and objects of study: delimiting a thematic space}

As writing studies may entail both teaching and research, it is important to describe which of these activities emerge as favored by the informants and what kind of teaching and/or research activities they engage in. Do writing teachers also conduct research? Are writing program administration positions common among scholars? Do writing scholars also teach in postgraduate programs? These research questions can help understand the configuration of the field.

In addition, tracing the preferred themes and objects of study is one of the ways to understand a field's disciplinarity. In principle, central trends might be an indication of well-defined research spaces, whereas high dispersion of objectives might be useful for understanding the diversity of theoretical approaches sustaining them. Diversity of research objects has been characteristic of the field in other parts of the world (Ritter \& Matsuda, 2012). In a previous study (Navarro et al., in press), we approached objects of study in research papers on reading and writing in
Higher Education from four Latin American countries; our results showed that discourse(s), students' reading and writing, and teaching were predominant objects of study; however, we also found that these preferred themes varied greatly in each country.

\subsection{Theoretical approaches and influences: eclecticism and hybridation}

To characterize writing studies as an emerging discipline, it is useful to trace what influences and theoretical approaches are most used. In previous studies of Latin America we have discovered an interesting level of eclecticism within the field, as well as a varied array of influences from different disciplines and parts of the world (Navarro et al., in press; Ávila Reyes, submitted).

But this eclecticism might be rooted in the nature of writing studies in general, as it can be seen as an interdisciplinary endeavor. Bazerman (2011) underlines the complex nature of writing itself:

$$
\begin{aligned}
& \text { Consequently, an understanding of what } \\
& \text { writing is and does and how people learn to do } \\
& \text { it must draw on the hermeneutic and rhetorical } \\
& \text { disciplines of the humanities along with the } \\
& \text { disciplines of the mind, society, history, and } \\
& \text { technology. Even more the understanding } \\
& \text { must integrate these perspectives into seeing } \\
& \text { writing as a unitary act (8). }
\end{aligned}
$$

Complexity of writing, the author argues, enables both eclecticism and tolerance of diverse research approaches, "along understanding of procedures, theories, and ideas" (9). From a different perspective, nonetheless, theoretical eclecticism might also be enabled by boundary crossing inherent to early stages of disciplinary formation (Klein, 1996).

The interest in tracing theoretical approaches and influences is twofold: on the one hand, it is useful to identify potential parent disciplines (i.e. traditional disciplines), and their epistemologies, for example, Psycholinguistics or Genre Analysis in the case of Linguistics. On the other, it might show theoretical eclecticism that is rooted in cross disciplinary traits, 
such as borrowing of tools, methods, concepts or theories; location of problems outside strict disciplinary focus; relations with disciplines, redefinitions of what is intrinsic to a discipline, and so on. All these reasons for permeation are grounded in the character of disciplines (as non-isolated units), formed by specialties that may require newer resources to fulfill their aim (Klein, 1996).

\subsection{Discipline in charge: jurisdictional dis- putes}

The interest of inquiring on which discipline should be in charge of writing studies is rooted in both the identification of parent disciplines and the emergence of disciplinarity claims in the discourse of scholars of the emergent field.

A discipline can be defined as "a form of social organization that generates new ideas and research findings, certifies this knowledge and in turn teaches this subject matter to interested students" (Jacobs, 2013, 29). We aim at tracing the existence of disciplines through the examination of not only disciplinarity claims made by interviewees (in terms of explicitly acknowledging a new field), but also paying attention to the ways in which the field is named, and to the sum of elements discussed throughout this section (i.e., landmarks of a common history, object of study and theory) that might account for the elements pointed out by Jacobs' definition. However, emerging disciplines might not completely fit in this description, as they have not constituted yet a well-defined set of knowledge claims that can be certificated.

Interdisciplinary studies offer an alternative perspective over spaces of academic exchange that occur as a consequence of the changing landscape of academia, catalyzed by new social groupings, practices and cognitive forms (Klein, 2000). Klein characterizes knowledge-making activities under two modes of functioning. Mode 1 is the traditional form of knowledge, "academic, homogeneous and hierarchical" $(1996,24)$; mode 2 entails, in contrast, a constant reconfiguration of resources, knowledge, and skills, which is primarily generated in hybrid forums of actors. An example of one instance of this kind of knowledge generation is the function of established professional organizations or networks as key sites "for developing hybrid interests and launching new groups" (25). Therefore, it will be important to cross-check with the acknowledged milestones to see whether this might be the case for writing studies in the region.

Boundary claims emerge when the competence of a discipline for solving a social problem is at stake. "The hybridity of interdisciplinary fields is at once their strength and a continuing source of difficulty [...] Multidimensionality is a vital stimulus but also a constant source of jurisdictional disputes" (Klein, 1996, p. 58). The concept of jurisdictional dispute was coined by American sociologist Andrew Abbott (1988) and refers to what occurs when a new phenomenon is established and two or more disciplines contend their pertinence to studying it. Abbott offers the example of the jurisdictional dispute over alcoholism, which can be seen as a crime (under law jurisdiction) or as a disease (under medicine jurisdiction).

In two separate previous studies, we found out that this is the case of the emerging community of practitioners of writing studies in Latin America, divided by jurisdictional claims made from parent disciplines, such as Linguistics (including Applied Linguistics) and Education (including Educational Psychology), embodied in differentiated research agendas and patterns of intellectual influence, as well as in differential disciplinary claims made in conferences and journal papers (Ávila Reyes, submitted; Navarro et al., in press). Jurisdictional claims and disputes are, nonetheless, a source that impels the emergence of professions (Abbott, 1988). In fact, it might represent an opportunity to rethink writing studies from a new hybrid discipline in the region that surpasses the dispute of the overlapping territories of Linguistics and Education.

\section{Methodological framework}

\subsection{Type of Research}

This article follows an interpretive paradigm, as it seeks to discover how a group of key participants experienced the emergence of the study of reading 
and writing in Higher Education in their countries. A qualitative methodology was used, in order to focus on the understanding and the analysis of the participants' points of view and the meaning that they attribute to several elements of the selected topic. Following Merriam (2009), basic qualitative research is often characterized by its focus on meaning and understanding of processes; it often relies on purposeful sampling techniques and uses interviews, observation and other documents as preferred data sources; lastly, data analysis is inductive and findings are usually presented as themes/categories. "The key concern is understanding the phenomenon of interest from the participants' perspectives, not the researcher's. This is sometimes referred to as the emic or insider's perspective" (Merriam, 2009, 14).

Since an interpretive perspective was assumed, the researcher is conceived as a "primary instrument" (Merriam, 2009; Patton, 2015); therefore, it is worth mentioning the background and origin of the authorial team. The authors come from three different countries. Different strategies were adopted to limit national bias, and to foster a more balanced approach to the data: 1 . All authors have cross-analyzed the samples; 2 . One of the four authors comes from out of the region; and 3. A fifth researcher from a fourth country peer-reviewed the codes (see section 3.4 below). In addition, some of the findings and trends were triangulated with other studies.

\subsection{Instruments}

This study corresponds to the second phase of a larger research project that started with an online survey responded to by 118 scholars (out of 321 invitations) from Argentina, Chile, Colombia and Mexico, in which they were asked about their scholarly activities related to writing in Higher Education. This phase's objective was to obtain detailed information as to how the scholarly interest for reading and writing has come about in the region.

As was mentioned before, one of the questions of this survey inquired about the academic leaders in the area. The results helped us to identify 8 key informants (see details below) who were then interviewed.
The objective of this interview was to explore their perspectives on the situation of Higher Education reading and writing studies in Latin America. The semi-structured interview posed 6 open questions. The enquiries dealt with topics such as: main academic and research activities, object of study, influential authors, milestones, obstacles, and perspectives on the study of reading and writing in Higher Education. These topics emerged from the results of the on-line survey given during the first stage of the ILEES investigation. Overall, the analysis of this information was intended to depict the origins, current situation, and possible developments of the field as perceived by leading scholars of the region.

\subsection{Participants}

A total of 8 academics, 2 from each country (Argentina, Chile, Colombia and Mexico), participated in the interview. All the interviewees are affiliated with universities or research centers in their countries. The following criteria were used in order to select the participants:

- Most referenced scholars in the ILEES survey, and/ or

- Editors of research journals on the topic, and /or

- Leaders of reading and writing initiatives (programs, conferences, networks) in the region.

Therefore, the participants are well-known scholars in the academic field, either because of their research production, or because of their promotion of local academic initiatives of reading and writing in Higher Education. Each participant was previously contacted in order to request their voluntary participation in an interview, following current standards of research on human subjects. ${ }^{1}$ The interviews were carried out in Spanish via Skype and lasted between 40 and 80 minutes. The audios were recorded on digital files using audio software (Audacity), and were then transcribed in orthographic transcription. The data turned in for 
each interview are treated as anonymous, omitting the participant's real name in favor of a system of general codes. In Table 1, the characterization and identification of the participants is comprehensively presented. In addition, data related to the interview's extension in terms of pages and number of words have been included. Quotations below from the transcripts are presented in the original Spanish and with our English translations.

Table 1. General Characteristics of the Sample

\begin{tabular}{|c|c|c|c|}
\hline ID* & Country & \# of Pages & \# of Words \\
\hline P1 & México & 11 & 6456 \\
\hline P2 & México & 9 & 4636 \\
\hline P3 & Colombia & 6 & 3143 \\
\hline P4 & Colombia & 7 & 4697 \\
\hline P5 & Argentina & 8 & 5322 \\
\hline P6 & Argentina & 10 & 5753 \\
\hline P7 & Chile & 9 & 5013 \\
\hline P8 & Chile & 10 & 5741 \\
\hline \multicolumn{2}{|c|}{ TOTAL } & 68 & 40761 \\
\hline
\end{tabular}

\subsection{Analysis of information}

To carry out this study, a Computer Assisted Qualitative Data Analysis (CAQDA) was performed. The initial stage recurred to CAQDA software QSR Nvivo 10, which facilitated storing, segmenting, and coding the interviews. This tool aided in the process of constructing theories based on the coding and management of a large quantity of information in the form of digitalized texts. Once the audio files were transcribed into Word processor documents, they were stored with an identification number. The analysis of information was carried out following the outline of tasks for data analysis proposed by Miles \& Huberman (1994), who state that the processing of qualitative data is divided into three phases of analysis: data reduction; synthesis and grouping; and verification of results. To this end, we followed Krippendorff (2004) content analysis framework, which indicates that it is possible to systematically interpret the semantic and formal components of the speech in order to make valid inferences from the data.

The data reduction phase consisted of two stages: 1. The detailed reading of the interviews and 2. The identification of segments of speech associated with a group of topics, or codes. In order to validate the first, exploratory analysis of the data, a protocol of categories, together with definitions and examples, was created. This protocol was peer-reviewed by three of the researchers on the ILEES team. It is worth mentioning that one of them did not take an authorial role in this study, and comes from a different country than the authors. Once the researchers expressed their agreement and opinions on the protocol, the leading author carried out the analysis of all the interviews, identifying the remaining categories and subcategories. To this end, each segment was associated with topics and subtopics, and classified in a tree data structure allowed by QSR Nvivo10 software. Lastly, the second author audited the coding and introduced changes when needed. The whole process was designed to deal with trustworthiness and credibility, as qualitative versions of validity and reliability traits (Merriam, 2009).

For the purposes of this article, we will focus on the following seven categories related to reading and writing in Higher Education. The definition of each category is presented in Table 2.

Table 2. Definition of pre-established categories

\begin{tabular}{|l|l|}
\hline \multicolumn{1}{|c|}{ Category } & \multicolumn{1}{c|}{ Definition } \\
\hline 1. Milestones & $\begin{array}{l}\text { Activities or events that initiate and/or consolidate the concern for reading } \\
\text { and writing in Higher Education. }\end{array}$ \\
\hline 2. Causes & $\begin{array}{l}\text { Reasons that explain the rise of the interest in studies on reading and writing } \\
\text { in Higher Education. }\end{array}$ \\
\hline 3. Influences & $\begin{array}{l}\text { Authors and/or scholars that have contributed to or influenced the } \\
\text { development of studies on reading and writing in Higher Education. }\end{array}$ \\
\hline $\begin{array}{l}\text { 4. Activitles } \\
\text { 5. Theoretical } \\
\text { approaches }\end{array}$ & $\begin{array}{l}\text { Scholarly activities the informant engages in. } \\
\text { Theoretical or methodological framework from which the informant } \\
\text { approaches studies on reading and writing. }\end{array}$ \\
\hline 6. Discipline in charge & Discipline or area responsible for reading and writing in Higher Education. \\
\hline 7. Future & Perspective of the studies of reading and writing in Higher Education. \\
\hline
\end{tabular}

This coding structure acted as a way of indexing the information, in order to help us track the relevant pieces of data to construct the offered interpretations (Gläser \& Laudel, 2013). Each of the categories was further analyzed by three of the authors, creating 
new subcategories emerged from data across all the interviews. This second layer of emergent coding was used as the basis for the proposed interpretations. The fourth author reviewed and supervised the analysis process, as the project's head.

Figure 1 below presents a node association model based on the coding. Larger nodes represent the initial analysis whereas smaller nodes are the result of the subsequent, emergent analysis. Arrows and distribution of small circles are automatically suggested by the qualitative analysis software NVivo from associations between pieces of speech; i.e., the program establishes relationships in terms of semantic proximity of the items. In total 7 categories and 49 subcategories (defined above) were hierarchically organized.

\section{Figure 1: Diagram of the coding system}

The interpretive analyses offered up next are the result of the detailed examination of the interview chunks labeled under each node. As the focus of the study is to understand the emic perspectives of participants, we do not offer generalizations, but rather, general trends that help making sense of the information provided by this particular group of practitioners regarding our research questions. In some cases, counts will be made as a complementary tool to weigh the extent of the consensus about an interpretation.

Each node is commented and some examples are provided to illustrate how the understanding of the phenomenon was constructed. In most of the cases, examples are used to illustrate how a similar point is made by different informants. When we do so, at least half of the interviewees had agreed on that view. In some other cases, an individual standpoint is considered

interesting enough to deepen its analysis, because it represents a valuable fact about the field's development that can be triangulated with external sources. In both cases, either shared understandings or individual standpoints, we have signaled the excerpts' function.

Regarding the scope of the analysis, a last issue to address is the degree of transferability of the results, which is known as external validity (Merriam, 2009). This inquiry, on the whole, seeks to aggregate knowledge to the historization and disciplinary identity of the field. Therefore, generalizations by country are not intended, and each of the interviewees is assumed to construct meaning about the field from their own experiences. Together, these testimonies can be offered as an ecologically representative landscape of the emerging field of reading and writing.

\section{Results and Discussion}

\subsection{Milestones}

The analysis of milestones showed 3 types of subcategories: initial academic events, key dates, and academic programs (see top left corner of Figure 1). Regarding academic events, four out of the eight informants relate the emergence of a scholarly interest in writing to a particular academic event, such as conferences and symposia:

1. Nosotros organizamos en el 2002 el séptimo congreso Latinoamericano para el desarrollo de la lectura y la escritura, México y Puebla fue sede en 2002 (...) hubo cientos de trabajos en donde si acaso 2 y a lo mejor soy exagerada eran sobre literacidad académica, o sea, hace 10 años no había nada (P1).

2. En 2001 hubo un congreso en la Universidad Nacional de Luján realizado por el departamento de educación de esa universidad, que convocó a todos los que estábamos por la escritura en la universidad (P5).

1. We organized in 2002 the seventh Latin American Congress for the development of reading and writing in Mexico, and Puebla hosted it in 2002 (...) there were hundreds of works, of which a maximum of two, and maybe
I am exaggerating were on academic literacy, that is, 10 years ago there was nothing (P1).

2. In 2001 a congress of the National University of Luján, organized by the Department of Education of that university gathered all of us working in the field of writing in the university (P5).

As for the key dates in the beginnings of the field, there is wide consensus that the scholarly interest on reading and writing studies in Higher Education started before or around the year 2000. Some of the interviewees linked this date with initial academic events (see above). This date is in accordance with what influential sources have stated in the literature (Carlino, 2013).

However, the informants were historicizing their accounts during the conversations, so there is not a single inaugural date. As a matter of fact, two of them referred to more than one founding milestone in different time ranges (P2: 1990s and 2000s; P3:1980s, 1990s and 2000s). For example an Argentinian informant claims that a first milestone can be traced back to 1984:

3. Un primer momento fue el año 84 , principalmente, en la Universidad de Buenos Aires (...) la cátedra de Elvira Arnoux (P6).

4. Tiene que ver con un momento político, específico en mi país, con el retorno a la democracia, que implicó en el año 84 (...) la ampliación del ingreso de nuevos públicos universitarios, de nuevos públicos a las universidades (P6).

3. Initially it was the year 84 , mainly at the University of Buenos Aires (...) Elvira Arnoux's chair (P6).

4. It has to do with a political moment, specifically in my country, with the return to democracy, which involved in the year 84 (...) the extension of the entry of new university audiences, new public universities (P6).

In this particular case, the interviewee refers to a political context that favored the beginning of the academic development of the area at the University of Buenos Aires. It is noteworthy that this initiative is associated with one influential scholar, Elvira Narvaja 
de Arnoux, widely mentioned in the survey and one of the three founders of the UNESCO Chair.

A third key date mentioned by an informant (P3) was 1994, when the UNESCO Chair was established. Although only one informant considered this event as a founding milestone, six of the interviewed scholars declared that this organization was responsible for the interest in reading and writing in each of the countries, as can be seen in the following interview extracts:

5. Lo asocio con la creación de la Cátedra UNESCO. La Cátedra UNESCO se crea en 1994 (P3).

6. Yo creo que ha sido clave, creo que la cátedra UNESCO ha sido clave (P7).

5. I associate it with the creation of the UNESCO Chair. The UNESCO Chair was created in $1994(\mathrm{P} 3)$.

6. I think that it has played a key role, I think that the UNESCO Chair has played a key role (P7).

In sum, regarding the key dates, one informant mentioned an early milestone in the mid 1980s; three situated the beginnings of the field by the 1990s, although two of them offered only triggering factors, such as theoretical and political conditions; whereas most of the informants coincide in dating the advent of the field by the 2000s decade. Additionally, most of the respondents agreed that the UNESCO Chair is the organization that promotes reading and writing studies at all levels of training in the region.

Lastly, academic programs do not seem to be considered relevant as founding milestones, since only one of the interviewees mentioned them (P2).

\subsection{Causes}

Regarding the causes, four of the informants reported two types of reasons for the emergence of studies in reading and writing in Higher Education (see top right node in Figure 1): one is contextual (excerpt 7), such as the exponential growth of enrolment in higher education, and other is theoretical (excerpt 8), such as the expansion of the field of psycholinguistics. In this regard, respondents commented that:

7.... tiene mucho que ver con lo que ha pasado en nuestro sistema educativo (...) en el hecho de que la universidad ha recibido masivamente a muchos más estudiantes que los que recibían antes (...) y los recibe con una formación que todavía está muy desnivelada respecto con lo que se espera de ellos en la universidad (P7).

8. ... las investigaciones en psicolingüística comienzan a poner el foco en educación superior, después de haberlo puesto en primaria, en secundaria lo mueven en educación superior (P8). 7. ... It has a lot to do with what has happened in our education system (...) the fact that the university has massively received many more students than they did before (...) and students come with an academic level that is still very uneven compared with what is expected of them in university (P7).

8. ... Research in psycholinguistics began to focus on higher education; after having focused on primary and secondary levels, it moved to higher education (P8).

Regarding contextual causes, informants pointed out that expanding university coverage evidences that first-generation college students bring scarce resources to meet their academic and university requirements. Actually, there is wide evidence of the increase of university enrollment in the region during the last decades and the challenges it posed for the new populations that this growth brought with it (Fernández Lamarra \& Costa de Paula, 2011). It seems that the force of events required that researchers address studies on reading and writing at university level. In parallel, psycholinguistic approaches that had been devoted to explaining the phenomenon in childhood began to clarify how this phenomenon also occurs in this educational level. This reconfiguration has also been noticed in studies about the field's published literature (Navarro et al., in press). Therefore, the reasons for the interest in studying college-level reading and writing are both contextual - social and institutional needs - 
and theoretical. Such conditions favored the diversity of approaches and perspectives to be discussed below.

\subsection{Influences}

To identify the theoretical influences, respondents were asked about the authors and the most influential theoretical traditions in the field. Responses reveal that authors are varied in number and in geographical distribution. In total, respondents refer to 70 authors from 17 countries. Figure 2 presents the quantitative distribution of the authors who were referred to on more than one occasion (self-mentions have been excluded). This graphic seeks to offer only a visualization of mentions within a qualitative, non-randomized, specific group of informants, in order to display how many times and by how many informants each influential author was mentioned. Vertical columns indicate the total number of mentions received by author. Colors identify different interviewees.

Figure 2. Mentions of influential authors by informants
(3 Argentines and 3 Chileans), 7 are from or work in the United States and Canada (Bazerman, Swales, Russell, Miller, Kintsch, Bereiter, Scardamalia), 2 are from Europe (Street, van Dijk), 3 are from or work in Australia (Rose, Martin, Halliday) and $\mathbf{l}$ is from Russia (Bakhtin). These data reveal that Latin America and the USA have the most decisive influence in our region. It also reveals the importance of Argentina and Chile in the region. Noteworthy is the absence of authors from traditionally influential countries, such as France and Spain.

Another feature that can be drawn from the graph is that authors are contemporary and were fully active at the moment of the survey (except for Bakhtin), something perhaps not as prevalent in the Humanities. This can be an indicator of the relative youth of the discipline. Additionally, most of the authors are mentioned by respondents from different countries indicating a regional consensus on their relevance (with the exception of Oyanedel, Harvey and Halliday, mentioned only by Chilean interviewees).

Lastly, and maybe the most interesting finding within this category of analysis, is that the authors



Of the 19 authors in Figure 2, a group of three authors stands out as the most mentioned: Charles Bazerman (11 mentions from 6 respondents from 3 of the countries involved), Paula Carlino (16 mentions from 5 respondents from 4 of the countries involved) and Giovanni Parodi ( 8 mentions from 3 respondents from 3 of the countries involved). The other authors obtained between 2 and 4 mentions from 2 or 3 of the respondents. A closer look at the authors mentioned more than once reveals that 6 are from Latin America cited as influences are not biased by the orientations of the informants. For instance, the two most prominent influential authors found, Bazerman and Carlino, more closely connected with the study of teaching and literacy practices, were cited by informants whose approaches and object of study were discourse analysis from linguistic perspectives. Therefore, this is a powerful indication of a cross-fertilization (Klein, 1996). In other words, the main influences of the emerging field are not biased by parent disciplines of origin of the 
researchers, configuring a powerful indication of the interdisciplinary nature of the emerging field.

\subsection{Activities}

In relation to the activities of key informants, six types of actions were identified. In decreasing order, they are: research (6 respondents), university teaching (3), consultancies (3), activities in writing centers (2), postgraduate programs (2), and publications (1). If categories are aggregated, there is a balance between research-oriented (research and publications--totaling 7) and teaching-oriented activities (university teaching, consultancies, and activities in writing centers--totaling 8); postgraduate programs (2) represent a hybrid activity that merges both research and teaching.

A review of excerpts on research reveals a strong concern for describing academic and professional genres used in higher education, and for finding out their associated activities:

9. Estamos trabajando sobre el conocer los materiales que leen específicamente los géneros, discursivos que leen los alumnos en diferentes disciplinas, en diferentes carreras de pregrado, de maestría y de doctorado (P8).

10. Actualmente estamos trabajando en un proyecto de investigación sobre géneros empresariales, es decir, géneros que se utilizan en las empresas en las que se insertan los graduados de las carreras de ingeniería (P6).

11. En esa investigación (...) recogimos una cantidad de información de datos monstruosa, volumen de información, porque caracterizamos 17 universidades en diferentes programas disciplinar ... (P4).

9. We are working in order to know the materials specifically read by students, genres, read in different disciplines and by undergraduates and postgraduates (P8).

10. We are currently working on a research project on business genres, i.e. genres used in the companies graduates of engineering programs work for (P6).
11. In that research (...) we collected a massive amount of data, huge information volume because we characterized 17 universities in different programs ... (P4).

University teaching is a common activity among respondents, especially in postgraduate education. This favors the work with apprentices to extend the field's development, as several informants that teach in postgraduate programs in Linguistics asserted. Only two informants, one from Argentina and one from Colombia, reported also being currently engaged in writing program administration activities.

Since research was identified as the most common activity informants engage in, it was necessary to further explore the preferred objects of study. Results indicated that objects of study are varied. Among this dispersion, the most frequent one is to describe academic texts circulating in the universities and professional circles. Additionally, studies on practices and dynamics that motivate reading and writing activities in Higher Education were identified. Some evidences are presented below:

12. ... mi centro de atención es cómo se construye el posicionamiento en las perspectivas en este ámbito (P2).

13. ... Hemos venido construyendo un panorama de los géneros que se leen en diferentes disciplinas y en diferentes niveles de la universidad (P8).

14. Las representaciones sobre la escritura académica, sobre su enseñanza (P6).

15. Me interesa hacer una integración entre las tres perspectivas de la argumentación más conocidas como son la retórica de Perelman (P3).

12. .... My focus is how positioning on perspectives is constructed in this area (P2).

13. .... We have been building a panorama of genres that are read in different disciplines and at different levels of the university (P8).

14. Representations on academic writing, about its teaching. (P6) 
15. I am interested in integrating the three perspectives of the argumentation, best known as the Rhetoric of Perelman (P3).

Responses revealed that research addresses a wide range of topics among which two poles stand out: discursive studies of university or professional writing, and studies of practices and representations of Higher Education reading and writing. Assuming this heterogeneity of subjects, and the variety of influential authors identified in section 4.3 , it is necessary to deepen the analysis of the theoretical frameworks that inform the interviewees, as presented in the next section.

\subsection{Theoretical Approaches}

As we presented in Figure 1 (middle right quadrant), four major subcategories of theoretical approaches can be identified in the analysis of the participants' answers: academic literacy, linguistics, rhetoric and education. Among them, Linguistics was extensively mentioned (42 times by the 8 respondents). Because of this high incidence we reanalyzed this subcategory, in order to find specific schools and theories. We were able to find, in decreasing order; Systemic Functional Linguistics (SFL), mentioned 17 times by 5 sources; Discourse Analysis (DA), mentioned 12 times by 4 sources; English for Specific Purposes (ESP), mentioned 6 times by 3 sources; Genre Studies, mentioned 6 times by 3 sources; and Psycholinguistics, mentioned once.

The distribution of mentions by informant is depicted in Figure 3. This graphic represents each time an informant mentioned a particular approach. Linguistics, however, is made up of individual mentions of each particular school (i.e., SFL, DA, ESP, and so on). Therefore, $62 \%$ of single mentions to theory correspond to linguistic schools.
Figure 3: Distribution of single mention of disciplines, by informant

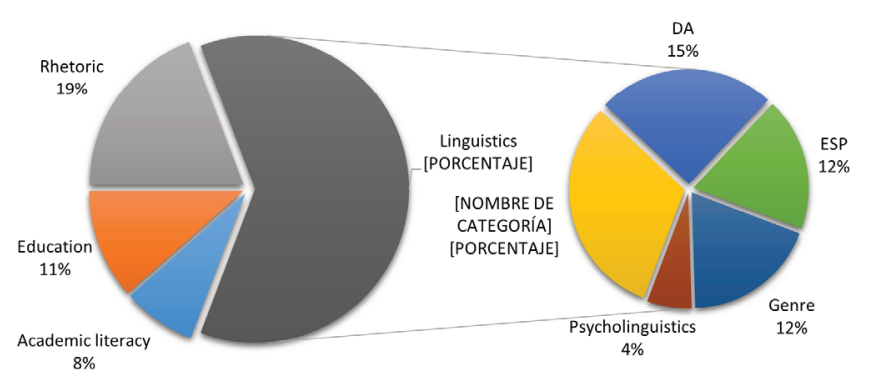

The following excerpts illustrate the variety of research approaches as described in the interviews:

16. Gran parte de la gente que está haciendo este tipo de investigación ha pasado por este programa de maestría entonces los estudiantes de este programa son también los que están realizando trabajos muy semejantes aunque quizás no tanto de la parte de la teoría de la apreciación, sino más bien de los enfoques derivados de la sistémico funcional (P2).

17. Desde la perspectiva de Swales también ese tipo de análisis - move analysis - de algunos géneros para conocerlos más en detalle, porque justamente si queremos enseñar a leerlos o queremos enseñar a escribirlos tenemos que conocer los rasgos de estos géneros en sentido lingüístico y retóricos (P8).

18. (Estamos) más centrados en dos géneros entonces por ejemplo, describieron que un tema importante es el ensayo, que el ensayo es un género específico de la universidad y que entonces el estudiante tiene que aprender a hacer ensayos y hay muchos trabajos sobre eso también (P1).

19. Yo me inscribo no solo desde una perspectiva estructural sino desde la dimensión dialógica bajtiniana, entonces insisto en la importancia del enunciado como unidad que permite recoger todo el escenario social y cultural (P3).

16. Many of those doing this type of research have taken this master's program, so students of this program are also those who are doing very similar work, although not so much about the theory of appraisal, but about the approaches derived from Systemic Functional Linguistics (P2). 
17. From the perspective of Swales, also this type of analysis - move analysis - of some genres to know them in more detail, precisely because if we want to teach how to read them or how to write them, we must know the linguistic and rhetorical characteristics of these genres (P8).

18. (We are) more focused on two genres, so for example, they reported that an important issue is the essay, that the essay is a specific genre of college and then the student has to learn to write essays and there are many works on that too ( P1).

19. I focus not only on the structural perspective but also on Bakhtin's dialogic dimension; then I insist on the importance of the enunciation as a facilitating unit in order to collect the entire social and cultural scene (P3).

In these examples, scholars refer to influential frameworks such as Systemic Functional Linguistics (P2) and Swales' move analysis to study genre in English for Specific Purposes (P3); they show their interest in genres, although the framework remains implicit (P1); and they mention Discourse Analysis key concepts such as "dialogic dimension" and "enunciation" and influential author Bakhtin. In sum, informants reveal a close connection to contemporary linguistic theories and a strong interest in socio-discursive approaches and educational approaches.

\subsection{Discipline in charge}

As indicated before, studies in the area have been conducted from different disciplinary houses. Previous results (Bazerman et al., 2016) show that in Latin America there is no exact correspondence between reading and writing studies and a single discipline or academic unit. Respondents of the survey conducted in the first phase of this research (see Methods, section 3.2. "Instruments") indicated that teams in charge of reading and writing issues in Higher Education are housed in varied departments, such as Linguistics, Education, Humanities, University Services, Science, Economics, Hispanic Studies, Communication, Speech Therapy or university research units. Given the broad spectrum of these responses, we were interested in knowing the opinion of the eight key informants regarding what the best disciplinary housing for such studies would be. We showed them a graphic with the survey answers and asked for their perspectives. The analysis of the results reveals that it is difficult to identify a single preferable discipline or university area. Interviewees assign this task, in descending order, to Education (8 mentions by 5 sources), Linguistics ( 9 mentions by 4 sources), Didactics ( 5 mentions by 3 sources), and efforts that are interdisciplinary or located "out of the disciplines", such as university service units (11 mentions by 3 sources). Only one informant mentioned "reading and writing" as a field on its own. Examples of this variety are shown below:

20. Diría que serían los servicios universitarios a mi juicio y eso sería como devolverle la responsabilidad a la institución pero la institución tampoco está ni preparada ni deseosa de hacerlo (P1).

21. Curioso que en educación es donde más se piensa, pero yo creo que en educación, yo pienso que sí, que las facultades de educación en Colombia son los espacios donde se está pensando la problemática de la escritura académica de la cultura académica más que en los departamentos de lenguas y los de ciencias en el lenguaje y comunicación (P3).

22. Donde hacemos investigación es lingüística y dentro de la facultad que es educación nosotros usamos lingüística. Tenemos doctorado y maestría en lingüística, no estamos tan vinculados con educación (P4).

20. I would say that at university services, from my view, and that would be like returning responsibility to the institution, but the institution is neither prepared nor willing to do so (P1).

21. It is curious that most people think about education, but I think that in education, I think that Faculties of Education in Colombia are the spaces where they are thinking about the problem of academic writing of academic culture, rather than in Departments of Language or Language and Communication Sciences (P3). 
22. We do research in Linguistics and we use Linguistics within the Faculty of Education. We have a Doctorate and a Masters in linguistics; we are not so linked to education (P4).

As can be seen, the disciplinary jurisdiction is not entirely clear, so that unresolved disputes are displayed and the institutional status of the discipline is still undetermined. These examples show how respondents alternatively refer to university services (P1), faculties of Education (P3) or Linguistics regardless of the home faculty (P4). Whereas most referenced disciplines are Education and Linguistics, claims for more integral, interdisciplinary approaches were also made by informants:

23. Yo creo que es un área absolutamente interdisciplinaria de la que tienen que participar especialistas en educación, en lenguaje y especialistas en las áreas específicas, digamos, y si fuera posible especialistas en el área que no trabajan en las universidades que conozcan el mundo real en el que se insertan los egresados de las carreras porque a veces es muy endogámica (P2).

23. I think that it is a completely interdisciplinary area which needs to involve specialists in education, language and specialists in, say, specific areas, and if possible specialists who do not work at universities, but who know the real world in which graduates participate because sometimes it [the academic world] is very inbred (P2).

These findings converge with the reflections of Klein (1996), who identifies permeable disciplinary boundaries as a characteristic of emerging topics of study. At the same time, it seems that reading and writing at university level is a disciplinary space disputed by different areas of knowledge, and university entities. Three of our respondents thematized this issue, stating the following:

24. Lo que se discute poco por escrito y más bien oralmente, en los congresos sobre todo quizás en la rivalidad entre grupos, no en rivalidades de grupo sino discusiones de quién es la potestad de escritura. Si de los especialistas en lingüística o si es una cuestión interdisciplinaria que (...) pluridisciplinar. Pienso que es... diríamos como discusión del campo teórico, creo que es es la discusión que hay que dar, que hay que argumentar por escrito (P5).

25. La investigación que se hace en lectura y escritura para poder formar al profesor de primaria está muy relacionada con la didáctica, y a veces lamentablemente está muy distanciada de los soportes teóricos que a mí me parece que son fundamentales, a veces existe lo que nosotros llamamos una especie de didactismo (P8).

26. Yo creo que no deberíamos ser mezquinos y tratar de hacer de esto una cuestión corporativa, que de esto se tienen que ocupar (...) yo estoy por la integración de miradas y la integración de esfuerzos porque es una tarea tan importante que merece que todos cooperemos (P6).

24. What has been scarcely discussed in writing and more frequently orally, mainly in conferences, maybe in the groups' rivalry, not in disputes in the group but discussions on who has the jurisdiction over writing? If it belongs to experts in linguistics or if it is an interdisciplinary subject that (...) pluridisciplinary. I think that it is... I would say a kind of a theoretical discussion, I think that this is the conversation we have to join in, that we have to discuss in writing (P5).

25. The research conducted on reading and writing to train primary school teachers is closely related to didactics, and sadly it is sometimes unrelated to the theoretical basis that seem essential to me, sometimes there is what we call a sort of didacticism (P8).

26. I think that we should not be mean and try to make this a corporate issue; that must be the concern (...) I am for the integration of views and integration of efforts because it is such an important task that everyone should cooperate (P6).

It is interesting to pay attention to lexical choices of these excerpts: Informant 5 talks about the existence of a rivalidad (rivalry) on the potestad (jurisdiction); and uses words such as interdisciplinaria (interdisciplinary) and pluridisciplinar (pluridisciplinary) to describe an ongoing argument. Informant 8 mentions that 
sometimes research in the area is lamentablemente (sadly) too much linked to didactics and too far away from theoretical support, what they call, pejoratively, didacticismo (didacticism), implicitly opposed to linguistic theory, which can be interpreted by reading the interview on the whole. Informant 6 includes words such as mezquinos (mean), and cuestión corporativa (corporate issue) to describe the pitfalls to avoid in the discipline's development.

\subsection{Future}

In regard to the future of the area, references were grouped in different subcategories: positive perspectives offered by 7 informants; negative perspectives, offered by 3 informants; and obstacles mentioned by 5 informants. For each subcategory an example is provided.

Positive perspectives:

27. Yo le veo mucha perspectiva positiva en ese momento, aunque siempre hay mucha resistencia al cambio, pero creo que sí, que finalmente se está abriendo cada vez más... se está haciendo más compartida esta idea de la importancia de la lectura y escritura, y en ese sentido empiezan a verse más programas a nivel universitario que aborden la lectura y escritura (P2).

27. I have a positive perspective of the field at the moment; although, there is always a lot of resistance to change, but I think that finally it is indeed opening up more and more ... the importance of reading and writing is becoming more widely shared. New programs on university reading and writing are becoming more common (P2).

Negative perspectives:

28. Yo pienso que ya va pasando de moda. Mi percepción es que se va a ir trasladando el interés a estudios mucho más puntuales, más locales (P4).

28. I think it is going out of fashion. My view is that the interest is going to gradually move to much more specific, local studies (P4).
Obstacles:

29. Tuve muchos obstáculos, o sea, yo pienso que la idea de que la enseñanza de la escritura ha seguido un enfoque pro disciplinar porque incumbe a la enseñanza de todas las materias, en todas las cátedras, de primer año, segundo, tercero, cuarto y quinto; y es muy poco sostenible (P5).

29. I had many obstacles, that is, I think that the teaching of writing has followed a pro disciplinary approach because it involves all subjects in all programs, first, second, third, fourth and fifth year; and it is hardly sustainable (P5).

There is a wide array of perspectives about the discipline's future development, ranging from considering that "it is going out of fashion" (P4) to stating that "it is indeed opening up more and more" (P2). Most of the participants (7) declared optimistic views, based on the emergent nature of the area, the vibrant expansion of educational offer in the region, and the construction of a common sense that reading and writing are important social matters; all of them reasons that favor the development of more research. Some informants even declared that research has a more promising future than teaching initiatives.

Paradoxically, a significant number of informants (6) also refer either or both to negative perspectives (3) or/and obstacles (5). These mentions include multiple references to a resistance from subjectmatter teachers or university administrators to adopt a writing across the disciplines perspective and become accountable for student's reading and writing in their courses. Indeed, five out of the eight informants asserted that this change would not be adopted by the professors in the disciplines. Furthermore, three of these informants linked this perception to the ongoing disciplinary disputes, which cast doubt regarding which university unit should be in charge of teaching reading and writing, as the following quotation illustrates:

30. Es un asunto de feudos, de tribus y de territorios académicos; que [la escritura] ha sido 
un área formativa en la universidad que se ha encargado a los lingüistas y literatos (P1).

30. It is a matter of feuds, tribes and academic territories; [writing] has been a teaching area that has been commissioned to linguists and literature teachers. (P1).

In this regard, these results confirm the existence of jurisdictional disputes as anticipated in section 4.6, about disciplines in charge (Abbott, 1988; Klein, 1996). Reading and writing studies in Higher Education comprise a permeable space to different disciplines, therefore a shared responsibility. At the same time, given its interdisciplinary character, it is a hybrid and multidimensional area disputed by different disciplines, mainly education and discourse-oriented linguistics. It can be said that this is an area of recent development which is, therefore, facing challenges and controversies.

\section{Discussion and Conclusions}

In this paper we aimed at answering two research questions: (1) Which are the milestones, influences, interests and activities related to Higher Education reading and writing teaching and research in Latin America?, and (2) Is this an emerging disciplinary space with a recognizable identity or a juxtaposition of scholars from different traditions interested in a single topic?

To answer the first question, we have discussed the milestones, activities, approaches, influences, disciplines involved, and future perspectives as presented from key informant's points of view; and interpreted them in terms of the field's disciplinary development. We are now able to offer a more comprehensive panorama of the field's development.

From a historical perspective, a systematic scholarly interest for reading and writing at Higher Educational level started at the beginning of the 2000s. Four interviewees from two countries reported four different pioneering academic events in that decade as founding milestones. Moreover, the participants identified the UNESCO Chair as an entity which has played a fundamental role, because it facilitated the expansion of the scope of the regional interest on literacy to Higher Education. An earlier, more distant precedent was detected in Argentina, where first-year writing course, developed and led by Elvira Narvaja de Arnoux, started by the mid-1980s facilitated by a propitious political context. Contextual causes were mentioned as triggering factors by other participants as well.

The importance of the UNESCO Chair is twofold. Firstly, it is a venue that has enabled the internationalization of this interest, which would be characteristic of the emergence of a new field according to Becher (1989). In fact, the present inquiry was made across 4 countries of the region with consistent results. UNESCO Chair is also the most recognizable academic network mentioned by six of the interviewees. UNESCO Chair was born as a network interested in reading and writing in general, across all levels and as a social, linguistic, educational or discursive object. However, its conferences have consistently gathered a significant number of Higher Education reading and writing specialists (see UNESCO, 2013). This means that the field is constituted as what Klein (1996) has termed "mode 2 of knowledge", which is primarily generated in hybrid forums of actors, enabled by crossdisciplinary dialogues and approaches, such as special interest groups within broader networks. Mode 2 of knowledge is a clear indication of the interdisciplinary nature of the emerging field.

Reported causes for the advent of writing studies included contextual and theoretical explanations. Contextual explanations comprise the rise of enrolment rates and democratized access to higher education in the region during the last decades; theoretical explanations refer to the switch from psycholinguistic reading research to discursive and communicative approaches to writing.

So far, there seems to be a perception of the unitary development of a hybrid, interdisciplinary field with certain milestones of a common history. However, the informants did not mention some of the traits that we presented as characteristics of institutional consolidation of a discipline: a specialized journal and specific doctoral programs (Goggin, 2000; Jacobs, 2013). Although we did not specifically ask about journals in the interview protocol, the previous stage of this research has shown that surveyed scholars were not able to identify a specific journal devoted to Higher 
Education reading and writing studies in the region (Bazerman et al., 2016). As for doctoral programs, only one participant referred to a postgraduate program on discourse analysis that prompted the field's development (see section 4.1). This might be an indication of an early stage of disciplinary development that may be traced in future studies of the subject.

Regarding activities, the informants mainly refer to their occupation as researchers. This result shows a relatively low level of participation of informants in administration and teaching writing and subject matters; on the contrary, they privilege their research activities in their accounts.

As for the research topics, declared objects of study are heterogeneous, just as reported for writing studies in other parts of the world (Ritter \& Matsuda, 2012). Despite the wide array of themes, they could be grouped in mainly two poles: analysis of academic discourse and student practices or representations of reading and writing in Higher Education. Both of these topics closely correspond to the main approaches and disciplines found in the analysis. These results are also partially coincident with our previous research (Navarro et al., in press) since we found that academic discourse and student's writing practices were among the main topics of study for the field.

Regarding approaches and disciplines, influences and theories are eclectic, and include diverse trends from Education and, predominantly, Linguistics. In tracking mentions of influential authors, one interesting finding stood out; main figures were acknowledged by informants across disciplinary boundaries. In other words, informants whose object of study and disciplinary preferences were clearly linguistic-driven mentioned authors such as Charles Bazerman or Paula Carlino as key influences; and, conversely, informants interested in teaching cited Chilean linguist Giovanni Parodi as a key influence as well. This suggests the existence of cross-fertilization, which is a form of interdisciplinarity. Theoretical eclecticism in writing studies is rooted in borrowing tools and theories from disciplines that might constitute together a broader, more comprehensive view on the subject (Bazerman, 2011).
As for disciplines in charge of writing studies, three academic units were mainly identified: University services (such as student support centers), Linguistics, and Education. Linguistics and Education can be clearly correlated with the influences and the objects of study declared by informants, and they are also the two main "parent" disciplines of the field. What is more, they embody the main jurisdictional disputes that we were able to find in the corpus.

When talking about disciplines and the future of writing studies in Higher Education, several informants made jurisdictional claims, or acknowledged the controversies within the field; even the word "jurisdiction" was used. Whereas some say that educational approaches lack a linguistically-informed view and become a sort of 'didacticism', others call for an interdisciplinary view that goes beyond language issues.

This is coincident with previous findings in our research, such as in Ávila Reyes (submitted) and Navarro et al. (in press). We found out that writing studies in Latin America are divided by jurisdictional claims made from parent disciplines, such as Linguistics (including Applied Linguistics) and Education (including Educational Psychology), embodied in differentiated research agendas and patterns of intellectual influence, as well as in differential disciplinary claims made in conferences and journal articles. Informants in this current sample also talked openly about the academic power disputes that these claims entail.

As for the second research question - Is this an emerging disciplinary space with a recognizable identity or a juxtaposition of scholars from different traditions interested in a single topic? - we found that, although there are jurisdictional disputes that might be rooted in the diversity of parent disciplines, there are also several indications of the development of a recognizable interdisciplinary emerging field. Some of the informants even talked about interdisciplinary and collaborative endeavors as the most promising perspective of the field.

However, our findings suggest that this recognizable, interdisciplinary, developing field is still emerging, and some clear elements of disciplinarity such as a distinctive professional organization and the establishment of specific doctoral programs and 
specialized journals are still lacking. Jurisdictional disputes might also be seen as a signal of this early stage of discipline formation.

We hope that this paper, offering a meta-disciplinary reflection of our field, might contribute to this development and the desired consequences of institutionalization and professionalization. It is still necessary to widen the scope to other countries of Latin America so as to provide a richer, more comprehensive landscape. This is, without question, a new challenge to study.

\section{Acknowledgements}

This work was partially funded by a University of California, Santa Barbara Academic Senate Research Grant (2012-2013); by The Conference on College Composition and Communication Research Initiative (2012-2014); by PIA-CONICYT Basal Funds for Centers of Excellence Project BF0003; and by PMI UCH1501 of the Ministerio de Educación, Chile. We would like to thank the 8 informants that collaborated with our research and Elizabeth Narváez-Cardona, for her valuable help during the research process.

\section{Note}

1. According to University of California Santa Barbara Human Subjects Committee protocols.

\section{References}

Abbott, A. D. (1988). The system of professions: An essay on the division of expert labor. Chicago: University of Chicago Press.

Ávila Reyes, N. (submitted). Postsecondary writing studies in Latin America: Intertextual dynamics and intellectual influence. London Review of Education, special issue on academic literacies.

Ávila Reyes, N., González-Álvarez, P., \& Peñaloza Castillo, C. (2013). Creación de un programa de escritura en una universidad chilena: estrategias para promover un cambio institucional. Revista Mexicana de Investigación Educativa, 18(57), 537-560.

Bazerman, C. (2011). The Disciplined Interdisciplinarity of Writing Studies. Research in the Teaching of English, 46(1), 8-21.

Bazerman, C., Kurt, R., Lunsford, K., McLeod, S. H., Null, S., Rogers, P., \& Stansell, A. (Eds.). (2009). Traditions of Writing Research. Oxford: Routledge/Taylor \& Francis.
Bazerman, C., Dean, C., Early, J., Lunsford, K., Null, S., Rogers, P., \& Stansell, A. (Eds.). (2012). International Advances in Writing Research: Cultures, Places, Measures. Fort Collins, Colorado: The WAC Clearinghouse/Parlor Press.

Bazerman, C., Ávila Reyes, N., Bork, A. V., Corrêa, F., Cristovão, V. L., Tapia Ladino, M., \& Narváez, E. (In Press). Intellectual orientations of studies of higher education writing in Latin America. In S. Plane, C. Bazerman, C. Donahue \& F. Rondelli (Eds.), Recherches en écriture: regards pluriels. Nancy: Université de Lorraine.

Becher, T. (1989). Academic tribes and territories: Intellectual enquiry and the cultures of disciplines. Milton Keynes England; Bristol, PA., USA: Open University Press/SRHE.

Bork, A. V., Bazerman, C., Correa, F., \& Cristovão, V. L. (2014). Mapeamento das iniciativas de escrita em língua materna na educação superior: resultados preliminares. Revista Prolíngua, 9(1), 2-14.

Cadena, S. y Narváez-Cardona, E. (Eds.) (2008). Los desafíos de la lectura y la escritura en la educación superior:caminos posibles. Cali: Universidad Autónoma de Occidente.

Carlino, P. (2005). Escribir, leer y aprender en la universidad: Una introducción a la alfabetización académica. Buenos Aires: Fondo de Cultura Económica.

(2013). Alfabetización académica diez años después. Revista Mexicana de Investigación Educativa, 18(57), 355-381.

Ciapuscio, G. E. (2007). Apuntes para una evaluación de los estudios lingüísticos en la Argentina. Hispanic Issues on line, 2, 121-130.

Fernández Lamarra, N., \& Costa de Paula, M. d. F. (2011). Introducción. In N. Fernández Lamarra \& M. d. F. Costa de Paula (Eds.), La democratización de la educación superior en América Latina. Límites y posibilidades (9-34). Tres de Febrero: EDUNTREF.

Gläser, J., \& Laudel, G. (2013). Life With and Without Coding: Two Methods for Early-Stage Data Analysis in Qualitative Research Aiming at Causal Explanations Forum: Qualitative Social Research, 14(2). Retrieved from http://www.qualitative-research.net/index.php/ fqs/article/view/1886

Goggin, M. D. (2000). Authoring a discipline. Scholarly journals and the post-World War II emergence of rhetoric and composition. Mahwah, NJ: Lawrence Erlbaum.

Haswell, R. H. (2005). NCTE/CCCC's Recent War on Scholarship. Written Communication, 22(2), 198-223. 
Jacobs, J. (2013). In defense of disciplines: Interdisciplinarity and specialization in the research university. Chicago: University of Chicago Press.

Klein, J. T. (1996). Crossing boundaries. Knowledge, disciplinarities, and interdisciplinarities. Virginia: The University Press of Virginia.

(2000). A conceptual vocabulary of interdisciplinary science. In P. Weingart \& $\mathrm{N}$. Stehr (Eds.), Practising interdisciplinarity. Toronto: University of Toronto Press. 3-24.

Krippendorff, K. (2004). Content analysis: An introduction to its methodology (2nd ed.). Thousand Oaks, CA: Sage.

Lincoln, Y. S., \& Guba, E. G. (1985). Naturalistic inquiry. Beverly Hills, CA: Sage Publications, Inc.

Merriam, S. B. (2009). Qualitative research. A guide to design and implementation. San Francisco: Jossey-Bass.

Miles, MB. \& Huberman, AM. (1994). Qualitative Data Analysis. Thousand Oaks, CA: Sage Publications.

Mollis, M. (2003). Las universidades en América Latina: ¿reformadas o alteradas? La cosmética del poder financiero. Buenos Aires: CLACSO. Retrieved from http://biblioteca.clacso.edu.ar/clacso/ gt/20101109010429/mollis.pdf

Navarro, F. (2012). Alfabetización avanzada en la Argentina. Puntos de contacto con la enseñanzaaprendizaje de L2. Revista Nebrija de Lingüística Aplicada a la Enseñanza de las Lenguas, 12(6), 49-83.

Navarro, F., Ávila Reyes, N., Tapia Ladino, M., Lopez Cristovão, V. L., Moritz, M. E. W., Narváez Cardona, E., \& Bazerman, C. (in press). Panorama histórico y contrastivo de los estudios sobre lectura y escritura en educación superior publicados en América Latina. Revista Signos. 49, special issue on academic literacy.

Parodi, G. (Ed.). (2010). Alfabetización académica y profesional en el siglo XXI: leer y escribir desde las disciplinas. Santiago de Chile: Ariel.

Patton, M. Q. (2015). Qualitative research and evaluation methods. Thousand Oaks, Calif.: Sage Publications. 4th edition.

Perales-Escudero, M. D. (Ed.). (2010). Literacy in Mexican Higher Education: Texts and contexts. Puebla: Benemérita Universidad Autónoma de Puebla.

Pereira, C. (2006). La lectura y la escritura en el CBC: memoria de la experiencia en la cátedra de Semiología. Paper presented at the Primer Congreso Nacional: "Leer, escribir y hablar hoy". Universidad Nacional del Centro de la Provincia de Buenos Aires, 28 de septiembre al 1 de octubre de 2006.

Poole, G. (2009). Academic disciplines: Home or barricades? In C. Kreber (Ed.), The university and its disciplines. Teaching and learning within and beyond disciplinary boundaries. New York: Routledge. 50-57.

Ritter, K., \& Matsuda, P. K. (2012). Exploring composition studies: Sites, issues, and perspectives. Logan Utah: Utah State University Press.

Thaiss, C., Bräuer, G., Carlino, P., Ganobcsik-Williams, L., \& Sinha, A. (Eds.). (2012). Writing programs worldwide: Profiles of academic writing in many places. West Lafayette, Indiana: Parlor Press \& WAC Clearinghouse.

Toulmin, S. R. (1972). Human understanding: The collective use and evolution of concepts. Princeton: Princeton University Press.

UNESCO (2013). Abstracts' book. Córdoba: Universidad Nacional de Córdoba.

Vallejos Llobet, P. (2005). Historia del discurso científico en la Argentina: una institución y sus textos a principios del siglo XX. Signo \& Seña, 14, 93-114.

Recebido em: 01/03/2016 Aceito em: 14/07/2016 